\title{
EVALUASI KETERSEDIAAN DAN KELAYAKAN JALUR EVAKUASI BENCANA DI MAL PANAKKUKANG KOTA MAKASSAR
}

\author{
Mayyadah Syuaib*, Nuryuningsih, Rohana \\ Jurusan Teknik Arsitektur \\ Fakultas Sains dan Teknologi UIN Alauddin Makassar \\ Jl. Sultan Alauddin No. 63, Kabupaten Gowa, Sulawesi Selatan. 92113 \\ *E-mail: mayyadahsyuaib7@gmail.com
}

\begin{abstract}
Abstrak: Sistem evakuasi yang baik menunjukkan bahwa kesiapsiagaan bencana memiliki peran penting khususnya pada bangunan publik. Penelitian ini bertujuan untuk menganalisis sejauh mana ketersediaan dan kelayakan jalur evakuasi dalam menghadapi kondisi darurat Mal Panakkukang Makassar. Metode penelitian yang digunakan adalah studi pustaka, observasi dan wawancara di lokasi. Hasil penelitian menunjukkan bahwa jalur evakuasi di Mal Panakkukang Makassar tersedia tetapi belum sepenuhnya memenuhi standar desain yang sesuai. Hal ini terlihat pada beberapa komponen di pintu keluar yang tidak sesuai dengan SNI 03-1746-2000. Tidak ada cukup titik pertemuan di luar gedung serta kurangnya tanda atau informasi tentang jalan keluar darurat. Penelitian ini diharapkan dapat membantu dalam pertimbangan perancangan bangunan publik agar memenuhi standar keamanan bangunan dan memenuhi hak masyarakat sebagai pengguna bangunan.
\end{abstract}

Kata Kunci: evakuasi, bencana, mal

\section{PENDAHULUAN}

$\mathrm{K}$

ota Makassar merupakan salah satu kota terbesar di Indonesia yang telah berdiri sejak tahun 1607. Berdasarkan data dari Badan Nasional Penanggulangan Bencana (BNPB), sepanjang tahun 2019 Kota Makassar pernah mengalami bencana banjir, yang terakhir tepatnya 22 Januari 2019 dan berdasarkan data BNPB dalam buku Indeks Risiko Bencana Indonesia tahun 2018, Sulawesi Selatan memiliki potensi ancaman bencana yang tinggi dengan nilai indeks risiko bencana 160,05. Untuk itu kesiapsiagaan menghadapi keadaan darurat dari segala jenis bencana harus diupayakan.

Undang-Undang Nomor 24 Tahun 2007 yang membahas mengenai Penanggulangan Bencana mendefenisikan bencana sebagai suatu kejadian atau keadaan yang mengganggu kehidupan dan penghidupan masyarakat, yang dipicu oleh kondisi alam dan non alam. Menimbulkan kerusakan jiwa manusia, kehilangan harta benda dan kerugian psikologis. Kedatangan bencana seringkali tidak dapat diprediksi sehingga masyarakat perlu memiliki pengetahuan untuk menghadapi situasi darurat. Salah satu bencana alam yang dapat menimbulkan bahaya lain yang akan mengikutinya adalah gempa bumi. Gempa bumi terkadang memakan korban lebih banyak, dibandingkan akibat gempa itu sendiri. Beberapa efek berbahaya lainnya yang biasanya terjadi setelah gempa bumi yaitu antara lain: (1) Tsunami; (2) Bangunan yang roboh; (3) Kebakaran; (4) 
Longsor; (5) Puing-puing bangunan; (6) Retakan tanah; (7) Kecelakaan industri seperti di Fukushima Jepang; dan (8) Banjir akibat runtuhnya bendungan dan tanggul serta pembatas lainnya (BNPB, 2012). Ragam jenis kondisi darurat dalam suatu bangunan, dibedakan dalam 3 kondisi, yaitu kondisi darurat karena alam (contoh: gempa bumi, banjir, badai dsb) kondisi darurat disebabkan oleh manusia (contoh: kebakaran, terorisme dll), dan kondisi darurat yang timbul karena pemasalahan teknis (contoh: runtuhnya bangunan karena usia, dsb). Kondisi dan jenis keadaan darurat yang berbeda ini mempunyai efek terhadap sarana jalur evakuasi bangunan (Sumardjito, 2010)

Menurut Peraturan Menteri Umum Ketenagakerjaan Nomor 26 Tahun 2008 tentang persyaratan teknis bangunan gedung wajib dilengkapi dengan sarana pelarian yang dapat digunakan oleh penghuni gedung agar mempunyai waktu yang cukup untuk menyelamatkan diri dengan selamat tanpa terhalang oleh hal-hal yang disebabkan oleh keadaan darurat. Kesiapsiagaan merupakan rangkaian upaya yang dilakukan untuk menganatisipai bencana melalui pengorganisasian dan tindakan yang efektif dan efisien (UU R.I No. 24 Tahun 2007). Memiliki kesiapan dan keterampilan dalam menghadapi kondisi darurat dapat mengurangi dampak risiko yang mengancam keselamatan manusia. Sikap dan tindakan masyarakat saat keadaan darurat yang umumnya muncul saat keadaan darurat terjadi adalah panik dan menjadi sulit untuk berkonsentrasi, bahkan sebagian orang melampiaskan kepanikan dengan teriakan yang mengakibatkan keadaan semakin kacau dan biasanya tindakan yang timbul adalah mengikuti gerak-gerik yang paling banyak. orang-orang.

Salah satu bangunan publik yang perlu mendapat perhatian terkait ketersediaan sistem evakuasi yang baik adalah Pusat Perbelanjaan atau mal. Perkembangan mal di Kota Makassar sangat pesat, berbagai fasilitas yang baik untuk memenuhi semua kebutuhan yang ada di dalamnya. Tidak hanya transaksi jual beli saja namun berbagai jenis atau aktivitas lainnya dapat ditemukan di dalamnya sehingga masyarakat cenderung menjadikan mal sebagai tempat tujuan rekreasi pada akhir pekan dan hari kerja, baik masyarakat yang berasal dari Kota Makassar maupun yang luar kota makassar.

Mal Panakkukang didirikan pada tahun 1998 dengan konsep mal keluarga yang hingga saat ini masih dalam proses renovasi. Menurut makassartoday.com jumlah karyawan Mal Panakkukang Makassar berkisar 1500-3000 orang, dengan jumlah pengunjung diperkirakan setiap hari bisa mencapai 30.000 orang dan jumlah tersebut meningkat pada akhir pekan, terlebih pada saat sebelum dan setelah hari raya lebaran, natal atau hari vakansi lainnya.

Kesiapan Mal Panakkukang dalam menghadapi kondisi darurat perlu diperhatikan terutama dalam hal ketersediaan pintu keluar atau jalur evakuasi bagi karyawan, pengelola dan pengunjung. Ketersediaan pintu keluar atau jalur evakuasi yang tepat memiliki peran penting dalam membangun sistem keselamatan, guna memenuhi hak pengguna atas keselamatan bangunan terkait. Hal ini telah diatur dalam Peraturan Pemerintah 2205 dan Undang-Undang Nomor 28 Tahun 2002 membahas mengenai Bangunan Gedung. Jumlah pengunjung di Mal Panakkukang cukup tinggi. ditambah dengan situasi darurat yang datang selalu tidak terduga. Seperti teror bom yang terjadi pada 13 Mei 2019 yang terungkap hoax yang sempat bikin heboh dan mengakibatkan pengunjung mal berhamburan. Untuk itu diperlukan studi evaluatif mengenai jalur evakuasi di dalam gedung, dan penting untuk mengetahui sejauh mana pemahaman masyarakat tentang sistem keselamatan bangunan tersebut. Ketika pemahaman masyarakat tentang sistem keamanan gedung masih minim, kemungkinan besar akan menghambat proses evakuasi saat keadaan darurat terjadi. Penelitian ini bertujuan untuk 
melakukan studi evaluatif mengenai ketersediaan dan kelayakan jalur evakuasi di Mal Panakkukang Makassar dan untuk mengetahui sejauh mana pemahaman masyarakat (pengunjung dan pekerja) terkait kesiapsiagaan menghadapi keadaan darurat.

\section{METODE PENELITIAN}

Metode penelitian menggunakan analisis deskriptif, yaitu dengan mendeskripsikan sistem jalur evakuasi yang terdapat di Mal Panakkukang kemudian mengkomparasikan kondisi eksisting dengan Peraturan Pemerintah No. 26 tahun 2008 dan/atau SNI 03-17462000 tentang tata cara perencanaan dan pemasangan sarana jalur evakuasi di dalam gedung. Adapun sumber lain yaitu Peraturan Menteri Pekerjaan Umum yang umumnya sama dengan yang tertulis dalam buku SNI.

\section{HASIL DAN PEMBAHASAN}

Mal Panakkukang adalah salah satu pusat perbelanjaan terbesar di Makassar yang terletak di Kecamatan Panakkukang, Desa Masale, di antara Jalan Boulevard dan Jalan Pengayoman. Sebuah bangunan terdiri dari 4 lantai, berdampingan dengan Hotel Myko yang berdiri pada tahun 2016 hingga saat ini masih dalam proses renovasi, penataan dan perluasan ruang dan penambahan gedung parkir

\section{Sirkulasi Interior dan Eksterior}

Penataan sirkulasi di dalam dan di luar gedung tentunya berpengaruh pada kelancaran proses evakuasi. Sirkulasi di mal Panakkukang terbagi menjadi koridor utama berukuran 8-12 m yang terletak di gedung B, berupa kawasan melingkar dengan diameter $19 \mathrm{~m}$ dan koridor tambahan berukuran 2-4 m. Koridor utama ditemukan saat memasuki gedung mal di pintu utama dari area utara dan selatan. Koridor tambahan terletak di sebelah barat dan timur yang merupakan pintu samping tepat bersebelahan dengan tangga darurat.

Ruang luar Mal Panakkukang memiliki sistem sirkulasi linier, dengan 3 titik akses dan 5 titik akses, tidak terdapat papan petunjuk atau informasi mengenai posisi titik kumpul. salah satu ketentuan tempat berkumpulnya adalah cukup untuk menampung seluruh pengunjung agar terlindung dari hal-hal yang menimbulkan kepanikan namun kondisi eksisting menunjukkan tempat parkir memenuhi hampir semua lokasi ruang luar Mal Panakkukang.

\section{Analisis Fasilitas Jalur Evakuasi Koridor}

Jalur evakuasi adalah jalur penyelamatan yang menerus termasuk dan mengarah ke jalan ke luar selasar dari setiap bagian bangunan gedung ke tempat yang aman (Fattah et al., 2017). Sesuai Peraturan Pemerintah Pekerjaan Umum No. 26-prt-m- tentang sirkulasi yang dimanfaatkan sebagai pintu keluar akses dalam suatu kawasan yang memiliki jumlah pengunjung lebih dari 30 orang, harus didesain terpisah dari bagian lain bangunan dengan material dinding yang memiliki tingkat ketahanan api selama 1 jam dan sesuai dengan ketentuan penghalang api.

Pada Mal Panakkukang lantai satu koridor keluar mengarah ke pintu darurat barat, sisi kanan dinding bangunan cukup tahan api karena berada tepat di sebelah inti bangunan. Dinding kiri tidak memiliki ketahanan api karena menggunakan material calsieboard. Di bagian timur Mal Panakkukang koridor pintu keluar memiliki lebar $6 \mathrm{~m}$ melewati big tenant dan beberapa retail. Koridor memasuki akses pintu darurat, memiliki ketahanan yang cukup terhadap api karena berbatasan langsung dengan bangunan inti. 
Pada setiap koridor ada akses langsung ke ruang luar. Dalam hal ini Mal Panakkukang dapat dikatakan telah memenuhi persyaratan yang ditetapkan. Kondisi eksisting dapat dilihat pada Gambar 1.

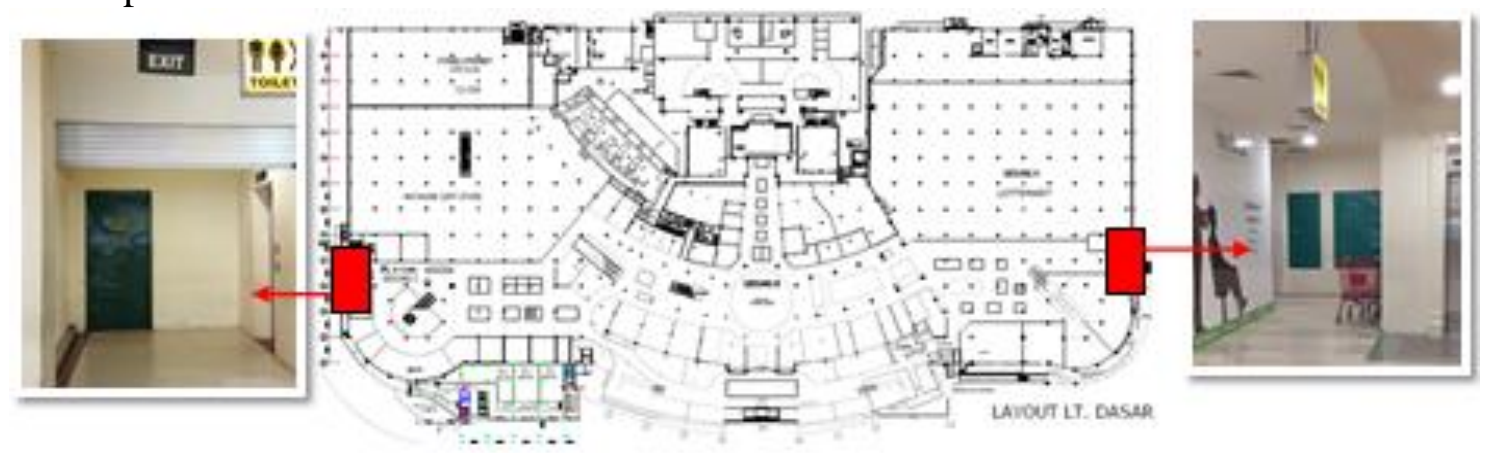

Gambar 1. Sirkulasi menuju tangga darurat (Dokumentasi Pribadi, 2020)

\section{Akses Keluar Bangunan}

Akses keluar dari Mal Panakkukang dapat dibagi menjadi empat bagian, yaitu melalui sisi barat, sisi timur, sisi selatan, dan sisi utara. Pintu keluar utara terdiri dari dua pintu utama yaitu pintu masuk dan pintu keluar. Satu pintu keluar melewati loket ATM, lima pintu keluar yang dapat diakses melalui beberapa restoran antara lain: Maxx Café, Texas Fried Chiken, Mama Hot Coated, dan Meet Ball Senayan. Pintu keluar bagian barat terdiri dari satu pintu utama dan satu pintu darurat. Akses tersebut adalah pintu masuk dan keluar, satu pintu untuk karyawan Lotte, serta empat pintu yang berfungsi sebagai aksesibilitas Lotte big tenant. Akses keluar di bagian utara terdiri dari satu pintu darurat untuk big tenant (Hypermart), satu pintu karyawan Hypermart, satu pintu darurat tepat di sebelah pintu masuk utama yang buka setiap jam operasional. Hal ini menunjukkan bahwa akses keluar Mal Panakkukang telah tersedia dari semua sisi, baik dari pintu darurat, pintu karyawan maupun umum.

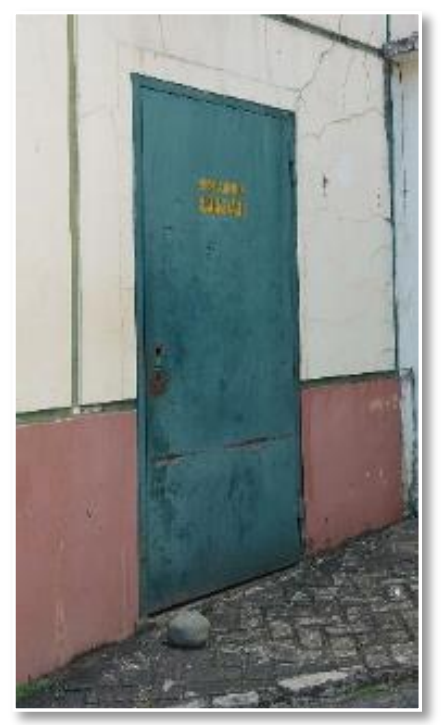

Gambar 2. Pintu darurat Mal Panakkukang (Dokumentasi Pribadi, 2020)

\section{Ketinggian Ruang Pada Akses Pintu Keluar}

Ketinggian ruangan pada akses keluar yang juga merupakan lobi lift Mal Panakkukang semuanya memiliki ketinggian yang sama yaitu tiga meter, telah melebihi ketinggian yang ditentukan dalam SNI 03-1746-200 yaitu 2,3 m ( $7 \mathrm{ft}, 6$ inci). Hal ini 
menunjukkan bahwa ketinggian pintu keluar akses Mal Panakkukang sudah sesuai dengan standar yang ditentukan.

\section{Keandalan Akses Keluar Bangunan}

Sesuai ketentuan SNI 03-1746-2000 fasilitas jalan keluar bangunan harus dijaga secara berkesinambungan, bebas dari segala halangan untuk digunakan secara penuh saat terjadi kebakaran atau kondisi mendesak/darurat lainnya. Kondisi eksisting di Mal Panakkukang menunjukkan jalur evakuasi berupa beberapa pintu darurat dan tangga darurat digunakan sebagai tempat penyimpanan barang atau gudang, hal ini menunjukkan bahwa secara realibilitas jalan keluar Mal Panakkukang belum memenuhi ketentuan SNI. 03-1746-2000. Kondisi tersebut dapat dilihat pada Gambar 3.
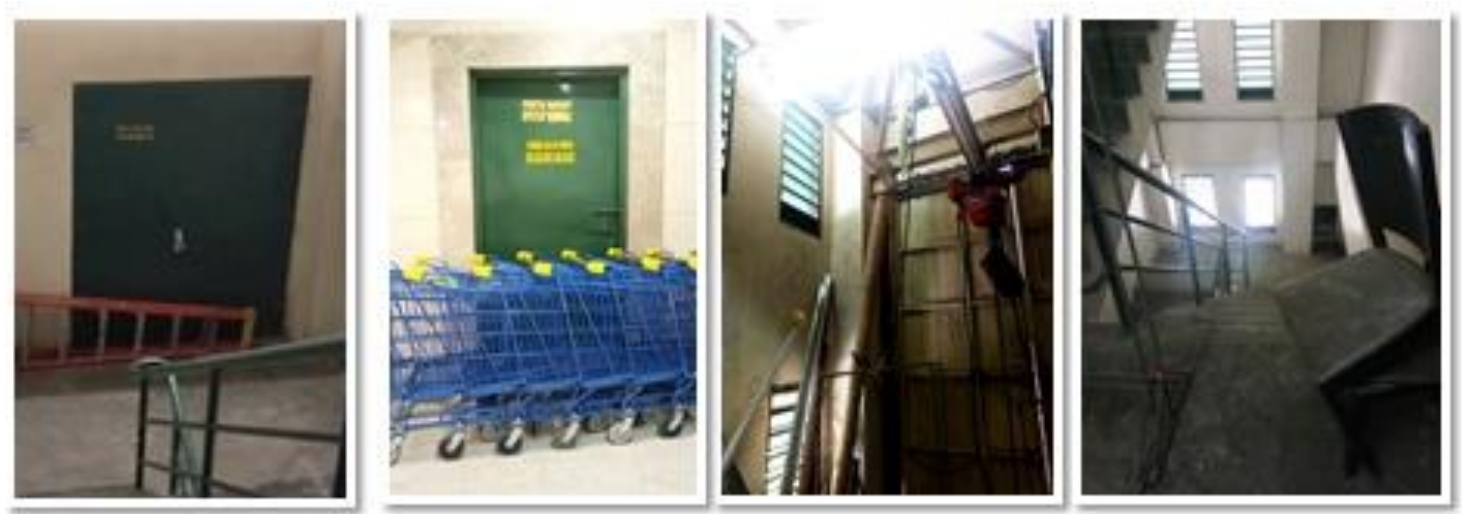

Gambar 3. Keandalan akses keluar bangunan (Dokumentasi Pribadi, 2020)

\section{Komponen Fasilitas Jalan Keluar Pintu}

Fasilitas bukaan pintu jalan keluar berukuran lebar $1 \mathrm{~m}$ dan tinggi $2 \mathrm{~m}$. Hal ini sesuai dengan ketentuan SNI 03-1746-2000 yang mengatur bahwa ukuran pintu harus mempunyai lebar minimal $80 \mathrm{~cm}$ (32 inci). Pintu darurat Mal Panakkukang didesain dengan warna mencolok sehingga mudah ditemukan. Menurut SNI 03-1746-2000 level lantai pada kedua sisi pintu tidak boleh berbeda lebih dari $12 \mathrm{~mm}$ (1/2 inch). Secara umum akses pintu keluar di Mal Panakkukang telah memenuhi standar yang ditetapkan namun masih terdapat beberapa pintu keluar yang memiliki ketinggian lantai yang berbeda pada kedua sisi pintu, seperti pada pintu darurat lantai dasar terdapat perbedaan ketinggian sekitar $5 \mathrm{~cm}$, dapat memperlancar proses evakuasi.

\section{Gaya Membuka Pintu, Kunci dan Grendel}

Mengacu pada Peraturan Menteri Pekerjaan Umum No. 26 prt-m-2008 pintu tahan api yang dibutuhkan dari jenis engsel atau jenis bukaan harus terbuka ke arah luar. Kondisi Pintu darurat Mal Panakkukang yang ada dengan material baja berukuran lebar $1 \mathrm{~m}$ dengan ukuran tinggi $2,5 \mathrm{~m}$, memiliki tipe poros ayun yang membuka keluar gedung. Dalam hal ini pintu darurat Mal Panakkukang telah memenuhi ketentuan yang berlaku.

Berdasarkan SNI 03-1746-2000, pintu darurat harus diatur agar siap dibuka dari sisi pintu keluar pada saat bangunan ditempati, tidak memerlukan kunci, tersedia alat pembuka dari dalam gedung. Kondisi pada bangunan Mal Panakkukang telah memenuhi standar meskipun masih terdapat pintu darurat yang mengalami kerusakan pada bagian kunci dan grendel. 


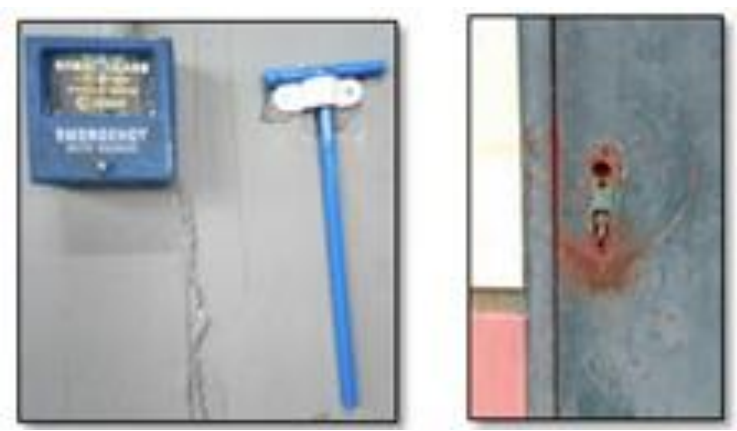

Gambar 4. Pintu dan grendel pintu darurat Mal Panakkukang (Dokumentasi Pribadi, 2020)

\section{Tangga Darurat}

Tangga yang digunakan sebagai komponen jalan menuju luar wajib memenuhi persyaratan umum tangga pada Tabel 1 yang merupakan tabel analisis kesesuaian tangga darurat dengan SNI 03-1746-2000. Berdasarkan tabel tersebut dapat disimpulkan bahwa tangga darurat di Mal Panakkukang telah memenuhi sebagian besar ketentuan yang tercantum dalam SNI 03-1746-2000 walaupun masih ada yang tidak memenuhi bahkan tidak tersedia.

Tabel 1. Analisis kesesuaian tangga darurat Mal Panakukang dengan SNI 03-1746-2000

\begin{tabular}{clccc}
\hline No & \multicolumn{1}{c}{ Persyaratan } & $\begin{array}{c}\text { Tidak ada } \\
\text { dan tidak } \\
\text { memenuhi }\end{array}$ & $\begin{array}{c}\text { Ada dan } \\
\text { tidak } \\
\text { memenuhi }\end{array}$ & $\begin{array}{c}\text { Ada dan } \\
\text { memenuhi }\end{array}$ \\
\hline $\mathbf{1}$ & $\begin{array}{l}\text { Tangga terbuat dari kostruksi beton/baja yang } \\
\text { memiliki tahan api selama } \pm 2 \text { jam }\end{array}$ & $\sqrt{ }$ & $\sqrt{ }$ \\
\hline $\mathbf{2}$ & $\begin{array}{l}\text { Memiliki tebal dinding beton minimum } 15 \mathrm{~cm} \\
\text { serta memiliki tahan api selama 2 jam }\end{array}$ & $\sqrt{ }$ & $\sqrt{ }$ \\
\hline $\mathbf{3}$ & Maksimum ketinggian anak tangga 19-20 cm & $\sqrt{ }$ & \\
\hline $\mathbf{4}$ & $\begin{array}{l}\text { Bahan bahan finishing seperti lantai dari bahan } \\
\text { yang tidak mudah terbakar dan tidak licin }\end{array}$ & & $\sqrt{ }$ \\
\hline $\mathbf{5}$ & $\begin{array}{l}\text { Tangga dan ram harus mempunyai rel pegangan } \\
\text { tangan pada kedua sisinya }\end{array}$ & & \\
\hline $\mathbf{6}$ & $\begin{array}{l}\text { Rel pegangan tangan pada tangga harus paling } \\
\text { sedikit 86 cm (34 inci) dan tidak lebih dari } 96 \mathrm{~cm} \\
\text { (38 inci) di atas permukaan anak tangga }\end{array}$ & $\sqrt{ }$ \\
\hline $\mathbf{7}$ & Lebar minimum 120 cm & & \\
\hline $\mathbf{8}$ & $\begin{array}{l}\text { Di dalam dan di depan tangga diberi alat } \\
\text { penerangan sebagai penunjuk arah ke tangga } \\
\text { dengan daya otomatis atau emergency. }\end{array}$ & $\sqrt{ }$ & \\
\hline
\end{tabular}

Berdasarkan Tabel 1 dapat disimpulkan bahwa tangga darurat pada Mal Panakkukang telah memenuhi sebagian besar ketetentuan yang dituliskan di dalam SNI 03-1746-2000, meskipun masih terdapat beberapa komponen yang masih belum memenuhi dan bahkan belum tersedia.

\section{Pelepasan Dari Eksit}

Eksit pelepasan adalah salah satu komponen penting dalam proses evakuasi, antara batas pintu eksit dan menuju jalan umum dengan posisi di luar bangunan gedung untuk kelancaran evakuasi ketika terjadi kondisi darurat. Pintu Eksit harus sesuai dengan ketentuan yang ditetapkan. Semua eksit harus berujung langsung pada jalan umum atau pada bagian luar lepas eksit. Site, halaman luas, open space, atau bagian-bagian lain dari lepas eksit harus memiliki luasan dan ukuran sesuai yang ditentukan untuk menyediakan 
akses yang aman ke jalan umum bagi pengunjung atau penghuni. Pelepasan eksit pada Mal Panakkukang berakhir pada site Mal panakkukang. Eksit pelepasan dari pintu darurat bagian barat berjarak $7 \mathrm{~m}$ dari jalan umum, eksit pelepasan dari pintu darurat bagian utara bertemu langsung dengan site mal dan berjarak $5 \mathrm{~m}$ dari jalan. Dalam hal ini pelepasan eksit Mal Panakkukang telah memenuhi standar yang telah ditetapkan SNI 03-1746-2000.

\section{Penanda Sarana Evakuasi}

Akses eksit pintu darurat dan jalur evakuasi selayaknya dipasang penanda dan pengarah yang mudah dibaca dan jelas. Hal ini telah diatur dalam UU No. 28 tahun 2002 tentang bangunan gedung serta Peraturan Pemerintah No. 36 tahun 2005. Dalam hal penanda pada sarana evakuasi Mal Panakkukang masih belum sepenuhnya memenuhi ketentuan yang telah ditetapkan sebagaimana ditunjukkan pada Tabel 2.

Tabel 2. Penanda sarana evakuasi Mal Panakkukang

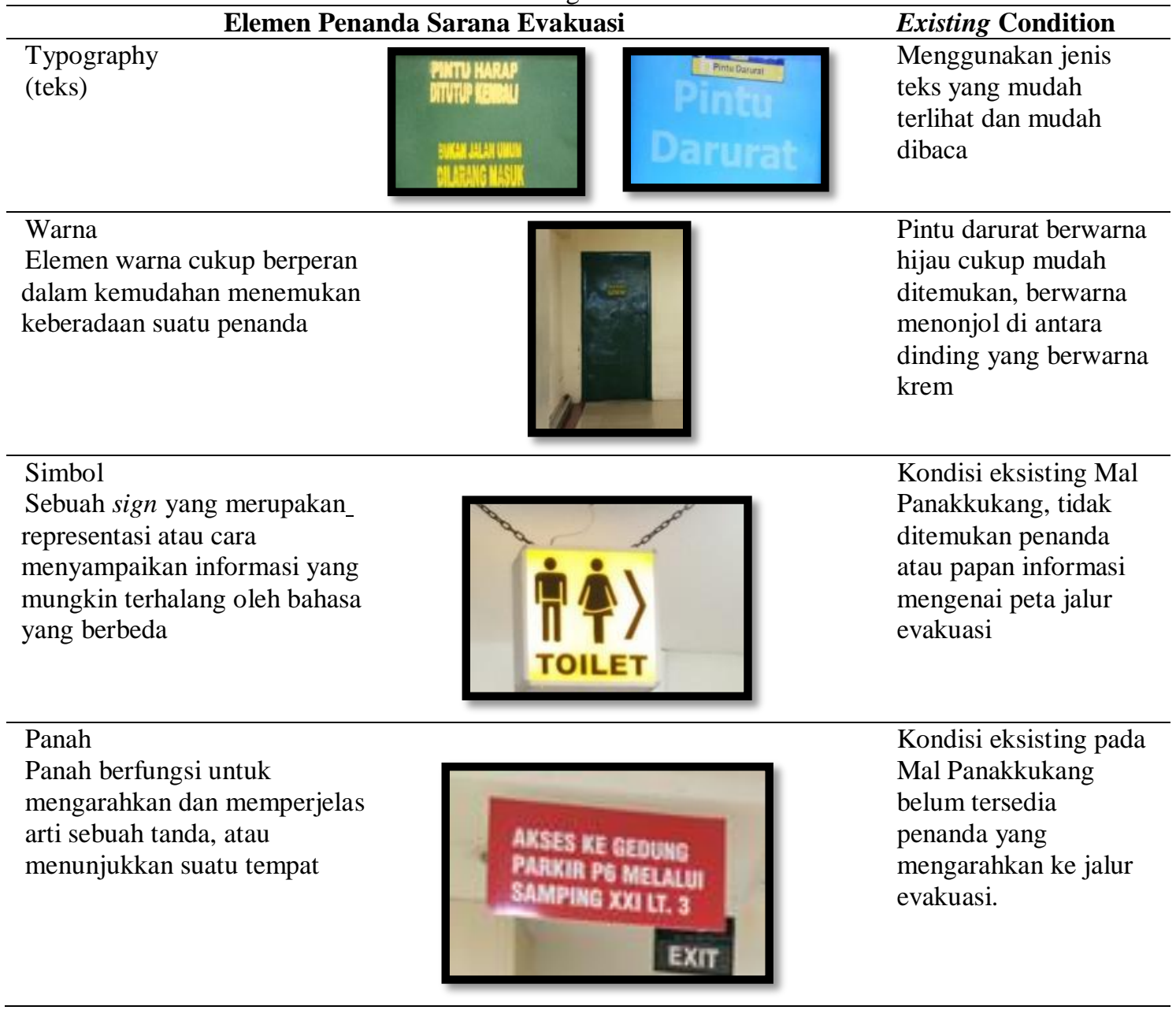

\section{Titik Kumpul (Assembly Point)}

Titik berkumpul merupakan sarana bagi pengunjung atau penghuni bangunan gedung untuk berkumpul setelah proses evakuasi. Desain dan perencanaan titik berkumpul harus memperhatikan beberapa hal, yaitu:

a. Ketepatan sebagai titik akhir dituju pada jalur evakuasi; 
b. Kemudahan dan keamanan bagi pengunjung/pengguna bangunan gedung untuk mengakses;

c. Posisi aman dari kemungkinan terjadi runtuhan bangunan gedung, ledakan dan lainlain;

d. Memungkinkan untuk dimanfaatkan secara komunal oleh seluruh pengunjung/penghuni gedung.

Pada area site Mal Panakkukang belum tersedia papan informasi untuk area titik kumpul dan belum tersedia ruang terbuka yang cukup memadai sebagai assembly point ketika terjadi kondisi darurat. Hampir sebagian besar area site Mal Panakkukang dimanfaatkan sebagai lahan parkir. Dalam hal ketersediaan titik kumpul, Mal Panakkukang belum memenuhi ketentuan yang ditetapkan dalam SNI 03-1746-2000.

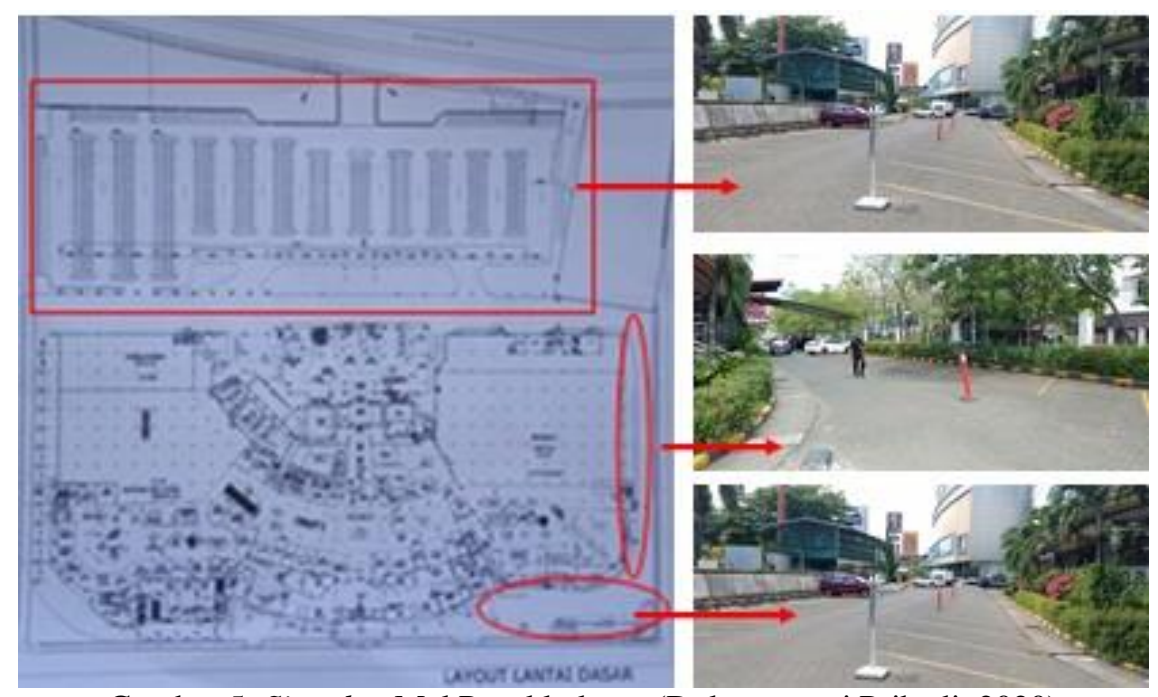

Gambar 5. Site plan Mal Panakkukang (Dokumentasi Pribadi, 2020)

\section{Pemahaman Pengunjung dan Karyawan Mal Panakkukang}

Pengunjung dan karyawan Mall Panakkukang sebagian besar telah mengetahui keberadaan jalur evakuasi, tetapi berdasarkan hasil wawancara (Gambar 6), mereka belum mengetahui posisi tangga darurat, serta belum memahami penanda/sign yang memberikan informasi tetang jalur evakuasi. Harapan mereka adalah ketika kondisi darurat terjadi di saat yang sama ada pengarahan dari petugas keamanan untuk menunjukkan pintu darurat.

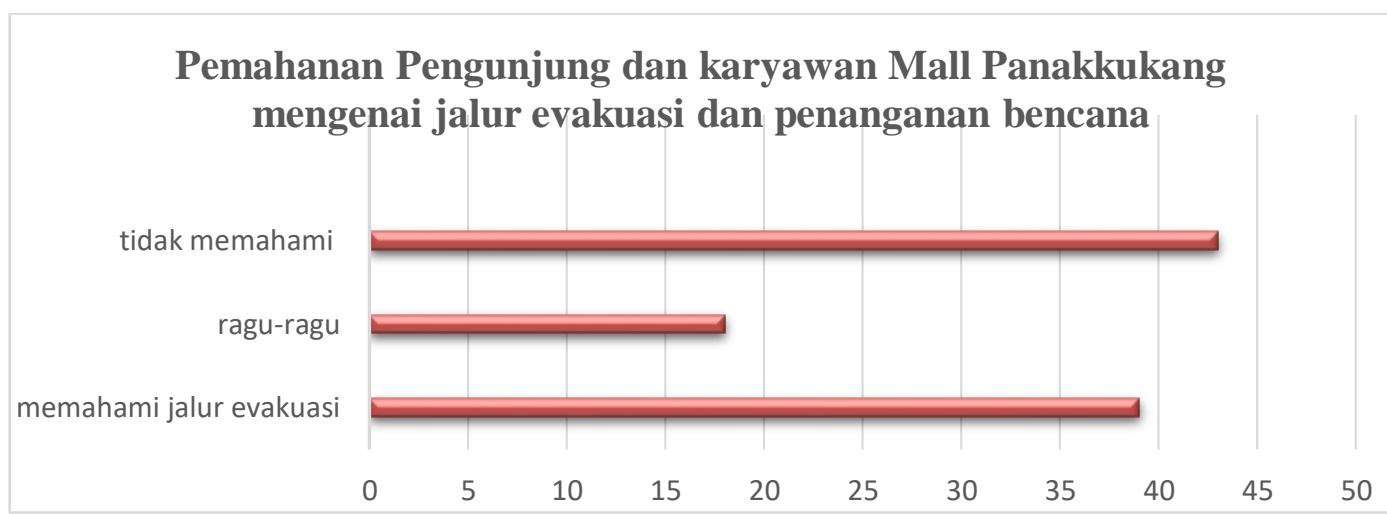

Gambar 6. Grafik pemahaman pengunjung dan karyawan tentang rute evakuasi Mal Panakukang 


\section{KESIMPULAN}

Sarana jalur evakuasi pada Mal Panakkukang telah tersedia dan beberapa bagian telah memenuhi Peraturan Pemerintah No. 26 tahun 2008 dan atau SNI 03-1746-2000, namun di beberapa bagian lain masih ada yang belum memenuhi ketentuan yang telah ditetapkan antara lain pada komponen jalan keluar yang terdiri atas: (a) Perbedaan ketinggian lantai pada akses eksit pintu darurat; (b) Belum tersedia penanda yang cukup jelas mengenai informasi jalur evakuasi dan assembly point (titik kumpul). Kelayakan jalur evakuasi Mal Panakkukang dapat dikatakan belum berjalan dengan baik dan dinilai belum siap menghadapi kondisi darurat. Hal ini terlihat pada keandalan sarana jalan keluar yang tidak sesuai dengan SNI 03-1746-2000, dimana area jalur evakuasi dimanfaatkan sebagai tempat penyimpanan barang.

Pengunjung Mal Panakkukang pada umumnya telah mengetahui keberadaan jalur evakuasi namun belum sepenuhnya memahami penanda yang bisa mengarahkan pengunjung pada posisi tersebut, berbeda halnya dengan karyawan dan SPG yang lebih banyak mengetahui akses eksit pada Mal Panakkukang.

\section{DAFTAR PUSTAKA}

Badan Nasional Penanggulangan Bencana. (2018). Indeks risiko bencana Indonesia. Jakarta: BNPB.

Badan Nasional Penanggulangan Bencana. (2018). Panduan kesiapsiagaan bencana. Jakarta: BNPB.

Badan Nasional Penanggulangan Bencana. (2012). Buku pedoman latihan kesiapsiagaan bencana tanggap tangkas tangguh menghadapi bencana. Jakarta: BNPB.

Bpbdkotamakassar.com diakses 17juli 2020.

Fattah, M. A., Afifuddin, M., Munir, A., Teknik, M., Program, S., Universitas, P., Kuala, S., Aceh, B., Sipil, J. T., Teknik, F., \& Kuala, U. S. (2017). Evaluasi jalur evakuasi di Bappeda Aceh. Jurnal Teknik Sipil, 6(2), 195-204.

Peraturan Pemerintah Pekerjaan Umum No. 26 PRT M 2008, Persyaratan teknis sistem proteksi kebakaran pada bangunan gedung dan lingkungan 2008.

Sumardjito. (2010). Emergency exit sebagai sarana penyelamatan penghuni pada bangunan-bangunan skala besar. Inersia, 6(1), 24-32.

SNI 03-1746-2000 Tata cara perencanaan dan pemasangan sarana jalan keluar untuk penyelamatan terhadap bahaya kebakaran pada bangunan gedung.

UU No. 24 tahun 2007 tentang penanggulangan bencana.

www.bnpd.go.id diakses 17 juli 2020. 